\title{
Activation of the hedgehog pathway in gastroesophageal cancers
}

\author{
Ling Yang ${ }^{1}$, Jingwu $\mathrm{Xie}^{2}$, Xiulan $\mathrm{Su}^{1}$ \\ ${ }^{1}$ Clinical Research Center of Affiliated Hospital, Inner Mongolia Medical College, Hohhot, Inner Mongolia 010050, China. ${ }^{2}$ Wells \\ Center for Pediatric Research, Department of Pediatrics and the Simon Cancer Center, Indiana University, Indianapolis, Indiana \\ 46202, USA. \\ Corresponding author: Ling Yang, Clinical Medical Research Center of Affiliated Hospital, Inner Mongolian Medical \\ College, No. 1 Tongdao North Street, Hohhot, 010050, Inner Mongolia, China. Tel: 86-471-6637588, Fax: 86-471-
} 6636128,Email: lingorangefan@gmail.com.

Accepted: $2011-10-11$

Published: 2011-11-23

DOI : $10.5430 /$ jst.v1n3p137

URL: http://dx.doi.org/10.5430/jst.v1n3p137.

\begin{abstract}
The hedgehog pathway is a major regulator for cell differentiation, tissue polarity and cell proliferation in embryonic development and homeostasis in adult tissue. Studies from many laboratories reveal activation of this pathway in a variety of human cancer, including basal cell carcinomas, medulloblastomas, leukemia, gastrointestinal, lung, ovarian, breast and prostate cancers. It is thus believed that targeted inhibition of hedgehog signaling may be effective in treatment and prevention of human cancer. Even more exciting is the discovery and synthesis of specific signaling antagonists for the hedgehog pathway, which have significant clinical implications in novel cancer therapeutics. In this review, we will summarize major advances in the last two years in our understanding of hedgehog signaling activation in human gastroesophageal cancer, and their potential in clinical treatment with hedgehog pathway inhibitors.
\end{abstract}

\section{Key words:}

Hedgehog; Inhibitor; Gastroesophageal cancer; Human cancer therapy

\section{NTRODUCTI ON}

The hedgehog $(\mathrm{Hh})$ gene was identified in 1980 through genetic analysis of segmentation of fruit fly Drosophila. ${ }^{1}$ In early 90's, three homologues of the Hh gene were identified in vertebrates. ${ }^{2-6}$ Overall, the general signaling mechanisms of the Hh pathway is conserved from fly to the humans. ${ }^{7}$ The seven transmembrane domain containing protein smoothened (SMO) serves as the key player for signal transduction of this pathway, whose function is inhibited by another transmembrane protein Patched (PTC) in the absence of Hh ligands. In the presence of active Hh ligands, binding of $\mathrm{Hh}$ to its receptor PTC releases this inhibition, allowing SMO to signal downstream, eventually to Gli transcription factors. As transcription factors, Gli molecules can regulate target gene expression by direct association with a specific consensus sequence located in the promoter region of the target genes. ${ }^{89}$ Figure 1 shows the simplified diagram of Hh signaling in the presence or absence of Hh. 

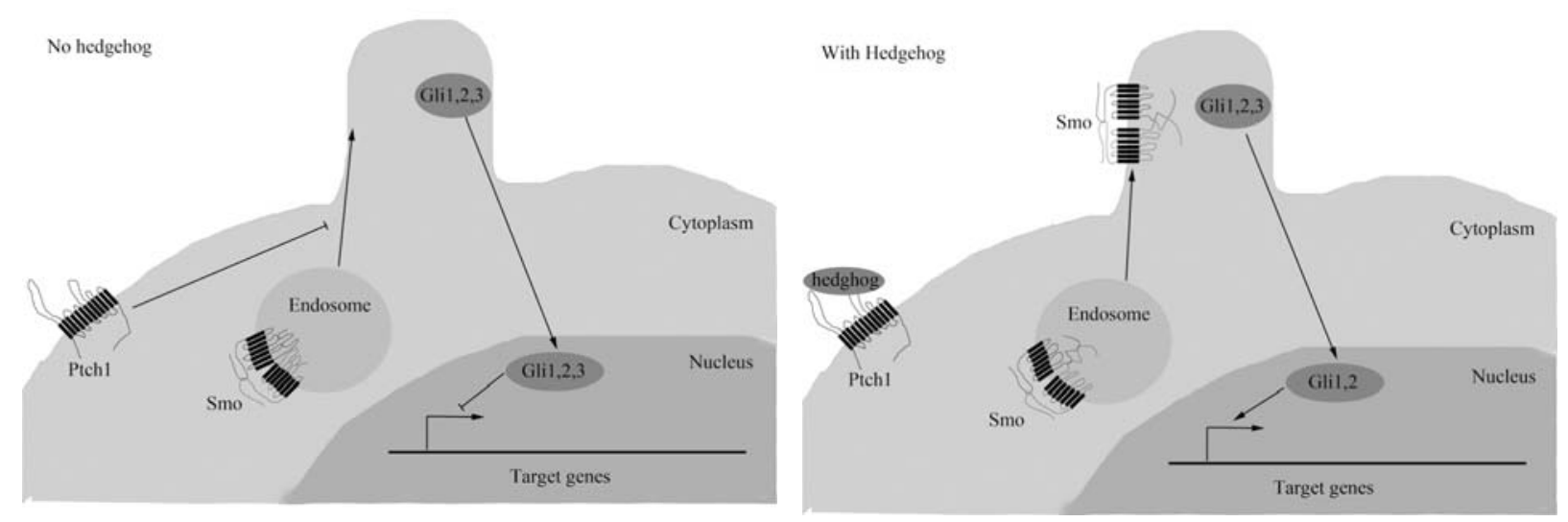

Figure 1 A simplified diagram of Hh signaling in vertebrates.In the absence of Hh ligands, PTC somehow inhibits SMO signaling, which results in formation of repressor forms of Gli transcriptional factors Gli2 and Gli3. In the presence of Hh ligands, SMO no longer affected by PTC, is signaling to downstream effectors, leading to formation of active forms of Gli transcriptional factors and ultimately activation of the target genes.

As an essential developmental signaling pathway, the Hh pathway is critical for maintaining tissue polarity and stem cell population. Inactivation of this pathway causes developmental defects such as holoprosencephaly, ${ }^{10}$ whereas hyperactivation of this pathway is found in most basal cell carcinomas (BCCs) and many extracutaneous cancers. ${ }^{11-13}$ In pancreatic cancer for example, activation of the Hh pathway is found in both early tumors and metastatic cancer ${ }^{14-18}$. In support of there findings, transgenic mice with pancreatic-specific expression of Shh or Gli2 develop pancreatic tumors. ${ }^{16,19}$ Pancreatic-specific deletion of SMO did not affect formation of pancreatic ductal adenocarcinoma (PDAC) whereas Gli2 expression resulted in undifferentiated pancreatic tumors. ${ }^{20,21}$ These studies indicate that activation of the hedgehog pathway is important but not sufficient for tumor formation of PDAC. It was shown that Kras directly activates the Hh pathway in PDAC cells. ${ }^{22}$ Activation of the Hh pathway is detected in stem cell-like subpopulation in pancreatic adenocarcinoma. ${ }^{23-25}$ Hh pathway inhibitors cyclopamine, ${ }^{26}$ IPI-269609 ${ }^{27}$ have effect in pancreatic cancer mouse model. Combination of Hh pathway inhibitor IPI-926 and gemcitabine, ${ }^{28}$ SMO antagonist SANT-1 and histone deacetylase inhibitor SAHA, ${ }^{29}$ Hh pathway inhibitor cyclopamine and inhibitor of epidermal growth factor receptor (EGFR) Iressa ${ }^{30}$ inhibit tumor cells in pancreatic cancer. The emerging role of Hh signaling in human cancer further emphasizes the relevance of studying this pathway to human health.

Cyclopamine, a plant-derived steroidal alkaloid, binds directly to SMO and inhibits Hh signaling. ${ }^{31}$ The discovery of small molecule antagonist of SMO has opened up exciting new prospects for target therapy and prevention of human cancers associated with Hh signaling. Six Hh pathway inhibitors (e.g. GDC-0449, BMS-833923, IPI-926 and PF04449913) have been used in clinical trials for treatment of basal cell carcinoma (BCC), medulloblastoma, ovarian cancer, lung cancer. ${ }^{32}$ GDC-0449, which was developed by Curis and Genentech, had great effects in therapy of advanced BCC and medulloblastoma. ${ }^{33,34}$ However, to our disappointment, clinical trials of GDC-0449 treatment in ovarian cancer and colorectal cancer have been suspended due to limited benefits for the patients. The remarkable differences in effectiveness of Hh pathway inhibitor in some types of cancer indicated that the Hh pathway plays different roles in different types of cancer. Therefore, in the future, thorough study is required before Hh pathway inhibitors are advanced into clinical trials. In this review, we will summarize major advances in Hh signaling activation in human gastroesophageal cancer to provide in-depth information for evaluation of clinical treatment with Hh pathway inhibitors.

\section{ACTI VATI ON OF THE HH PATHWAY I N ESOPHAGEAL CANCER}

Esophageal cancer is the $6^{\text {th }}$ cause of cancer-related death worldwide and the $7^{\text {th }}$ cause of cancer-related death in American men. ${ }^{35}$ The two types of esophageal cancer, squamous cell carcinoma (ESCC) and adenocarcinoma of esophagus (ACE), have different incidence in different geographic regions: squamous cell carcinoma of esophagus is still the predominant type worldwide. The incidence of adenocarcinomas is rising in the United States and several European countries. ${ }^{36-38}$ China is one of the countries with the highest incidence of esophageal cancer. ${ }^{39}$ It is known that the etiology of esophageal adenocarcinoma includes long standing acid/bile reflux esophagitis and development of Barrett's esophagus, an intestinal type metaplasia of the normal squamous epithelium which further progresses to 
dysplasia and carcinoma. Similarly, ESCC is considered to arise from multiple steps through progression of precancerous lesion-squamous dysplasia to invasive ESCC. Most esophageal cancers are diagnosed in the advanced stage, resulting in a high mortality. Current treatments of esophageal cancer include surgery, neoadjuvant chemotherapy or neoadjuvant radiochemotherapy followed by surgery, or surgery plus chemotherapy. The overall 5-year survival rate of esophageal cancer $(<10 \%)$ has not changed since 1980. Therefore, identifying sensitive and specific biomarkers for esophageal cancer will help early diagnosis and may help to design novel strategies for more effective targeted therapy for patients with advanced diseases.

Hh signaling activation has been reported in esophageal cancer. Previously, we and others found activation of $\mathrm{Hh}$ signaling in esophageal cancer. ${ }^{40-42}$ Elevated expression of sonic hedgehog (Shh) and its target genes have been found in several esophageal cancer cell lines and esophageal cancer specimens. ${ }^{42-45}$ Studies also suggest that Hh signaling activation is associated with poor prognosis ${ }^{44}$ of esophageal caner. Crosstalks among Hh signaling, the epithelialmesenchymal transition pathway, ${ }^{46}$ the phosphinositide-3 kinase pathway and mitogen-activated protein kinase pathway ${ }^{47}$ have been reported in esophageal cancer.

Compared with study of the Hh pathway in esophageal cancer, little is known about Hh signaling activation in precancerous lesions of esophageal cancer. Recent study indicates that Shh is induced in Barrett's esophagus to mediate paracrine Hh signaling. ${ }^{48}$ We also found that expression of PTCH1 is associated with occurrence of severe squamous dysplasia/ carcinoma in situ and Barrett's esophagus (our unpublished data). Consistent with the human specimen data, we found a high percentage of Hh signaling activation in precancerous lesions in rat models (our unpublished data). These data indicate that the Hh pathway activation is an early molecular event in the development of esophageal cancer and may be a target for early diagnosis and novel therapy for esophageal cancer. Activation of the Hh pathway in esophageal adenocarcinoma is much higher than in esophageal squamous cell carcinoma (our unpublished data), which may caused by more activation of the hedgehog pathway in Barrett's esophagus compared with squamous dysplasia and different etiology between ESCC and ACE, indicating that the Hh pathway in esophageal cancer may be context dependent and affected by tumor heterogeneity. Without knowing the status of Hh signaling, it will be difficult to predict the outcomes of Hh signaling inhibitors in cancer treatment. Several animal models have been used in the study of esophageal cancer, including surgical bilious reflux injury induced rat/mouse esophageal cancer model, ${ }^{48,49}$ NMBA induction of rat esophageal squamous cell carcinoma model ${ }^{50}$ and esophagogastroduodenal anastomosis induced rat esophageal adenocarcinoma model. ${ }^{51}$ These are useful tools in evaluation of effects of the Hh pathway inhibitors for esophageal cancer development and progression.

\section{ACTI VATI ON OF THE Hh PATHWAY I N GASTRI C CANCER}

The incidence and mortality have fallen dramatically over the past 70 years. ${ }^{52}$ However, gastric cancer is the fourth leading cancer following lung, breast, and colorectal cancer and the second cause of cancer related death worldwide after lung cancer. ${ }^{53,54}$ In 2002, approximately 930,000 people were diagnosed with gastric cancer and about people 700,000 died of this cancer. ${ }^{55}$ The best treatment option for gastric cancer is surgical removal of the tumor at early stages. Most patients with gastric cancer are diagnosed later in tumor progression, making it impossible to do surgery. Other therapeutic approaches include neoadjuvant chemotherapy, neoadjuvant chemoradiotherapy and adjuvant chemotherapy and palliative therapy, with only a slight improvement of patient survival or reduced pain of the patients. Event with the best intent to cure from clinicians, the overall 5-year survival of gastric cancer patients is 5\%-15\%.

Recent studies have shown that the Hh pathway is involved in gastrointestinal development and gastric regeneration. ${ }^{56-60}$ Molecules such as the transcriptional factors GATA-4, GATA-6, ${ }^{61}$ FoxF1, FoxL1, ${ }^{62}$ COUP-TFII, ${ }^{63}$ E-cadherin, ${ }^{64}$ $\mathrm{ERK}^{65}$ and epithelial-mesenchymal transition pathways, ${ }^{66}$ are reported to be associated with Hh signaling in this process. Paracrine Hh signaling is found in gastric patterning throughout murine embryonic and adult life. ${ }^{67}$ Gastric acid induces Shh gene expression. ${ }^{56,68,69}$ Aberrant expression of Shh is involved in the pathogenesis of gastric diseases such as gastric atrophy, ${ }^{70,71}$ hypergastrinemia and hyperproliferation of surface mucous cells. ${ }^{72}$ All these studies will help us to better understand the molecular mechanism of gastric diseases and optimize the strategy of treatment.

Increasing evidence shows that Hh signaling plays a role in gastric cancer. It is estimated that about $90 \%$ of gastric cancers are adenocarcinomas. According to Lauren Classification, there are two major types of gastric adenocarcinoma: intestinal and diffuse type. Several studies on activation of the Hh pathway in these two types show inconsistent results. Hh signaling is found to be more frequently and highly activated in the diffuse form, not the intestinal type. ${ }^{57}$ Low expression of Shh and high level of Cdx2 are found in metaplasia columnar epithelium. ${ }^{73}$ Shh expression is down regulated by $\mathrm{Cdx} 2$ in intestinal metaplastic mucosa of stomach from Cdx2-transgenic mice. ${ }^{74}$ Another study reports that 
expression of Shh is stronger in the intestinal type than in the diffuse type. ${ }^{75}$ Consistent with the role of Hh signaling in gastric cancer, loss of Gli3, an inhibitory component of the Shh pathway, results in intestinal transformation of gastric epithelium. ${ }^{59}$ Expression of Shh, Ihh, pathway components and target genes increases in gastric cancer, ${ }^{38,43,45}$ and gastric lesions are associated with the methylation status of the sonic hedgehog (Shh) promoter. ${ }^{76}$ Nuclear translocation of Gli1 was higher in undifferentiated-type tumors and positively correlated with lymph node metastasis in gastric carcinoma. ${ }^{77}$ Hh signaling was found to promote gastric cancer cells proliferation, ${ }^{78}$ epithelial-mesenchymal transition, ${ }^{66}$ mobility and invasiveness ${ }^{79}$ and inhibit apoptosis. ${ }^{43,80}$

Helicobacter pylori (H. pylori) infection is one of the major carcinogens in gastric cancer. H. pylori infection suppresses expression of Shh in gastric mucosa prior to neoplastic transformation ${ }^{81}$ and eradication of the infection restore Shh expression. ${ }^{82-84} \mathrm{H}$. pylori infection is also implicated in activation of the Hh pathway in gastric cancer. ${ }^{85,86}$ These studies indicate that $H$. pylori have different roles in Shh pathway in temporal and spacial dependent manners during gastric carcinogenesis.

Crosstalk between the Hh pathway and other signaling in gastric cancer has been reported. Mitogen-activated protein kinase cascade promotes activation of the Hh pathway in gastric cancer cells. ${ }^{87}$ Activation of the Wnt pathway is reversely correlated with activation of the $\mathrm{Hh}$ signaling in gastric cancer, ${ }^{88,89}$ probably through inhibition of the Wnt pathway by $\mathrm{Hh}$ target gene sFRP1. ${ }^{89,90}$ A recent study provides evidence that the estrogen receptor-alpha pathway promotes gastric cancer cells proliferation by activating the Hh pathway. ${ }^{91}$ Expression of Shh signaling components is also found in precancerous lesions of gastric cancer, ${ }^{75}$ indicating that the Shh pathway is involved during early gastric carcinogenesis.

\section{Hh SI GNALI NG I N GASTROESOPHAGEAL CANCER STEM CELLS}

The definition of cancer stem cell, "a cell within a tumor that possesses the capacity to self-renew and to cause the heterogeneous lineages of cancer cells that comprise the tumor", was reported in AACR Workshop on Cancer Stem Cells in 2006. ${ }^{92}$ Study of acute myeloid leukemia in 1997 found that a subpopulation could initiate cancer in NOD/SCID mice resemble of histology of cancer from donors, ${ }^{93}$ which provided evidence for the existence of cancer stem cells. Currently, there are four methods to detect cancer stem cell, including cell surface markers, side population, tumorspheres formation and inoculation in NOD/SCID mice. Since cell surface markers or side population alone may not represent the cancer stem cells in solid tumors, it is necessary to use more than one method to detect cancer stem cells.

Several cell surface markers are found to be potential markers to separate gastric cancer stem-like cells in cancer cell lines and specimens. CD44+ subpopulation in gastric cancer cell line MKN-45, MKN-74 and NCI-N87, ${ }^{94}$ CD44, CD24 and CD133 positive HGC-27 cell line ${ }^{95}$ forms tumorspheres in vitro and initiates tumor in vivo. Expression of CD133 and Bmi-1 are detected in cancer specimens, and CD133 is correlated to invasion and prognosis of gastric cancer. ${ }^{96,97}$ Side population cells isolated from cancer cell lines MKN-45, OCUM-2M, OCUM-2D, OCUM-2MD3 possess the characteristics of cancer stem-like cells..$^{98,99}$

Studies have revealed the several possible origins of gastric cancer stem cell. Chronic inflammation induced by H. pylori infection recruits bone marrow-derived cells, and these cells go through metaplasia, dysplasia to cancer. ${ }^{100,101}$ Gastric epithelial stem cells may be the cellular origin of gastric cancer. ${ }^{102,103}$ Under mucosal injury and inflammation, mature gastric chief cells act as cryptic progenitors and reacquire the ability of proliferation. ${ }^{104}$

Study of Hh signaling in gastric cancer stem cells has just begun. Tumorspheres of HGC-27 cancer cell line and specimens express high level of Ptch and Gli1. Hh signaling blocked by 5E1 or cyclopamine causes reduction in selfrenewing capacity. ${ }^{95}$ The Hh pathway is widely studied in cancer stem cells of glioma, ${ }^{105-107}$ breast cancer, ${ }^{108,109}$ myeloid leukemia, ${ }^{110,111}$ and find that the Hh pathway is essential to maintain characteristics of cancer stem cells. Therefore, we believe that the mechanism how Hh signaling involved in the gastric cancer initiation and progress through regulating gastric cancer stem cells will be revealed soon in the future.

Bone marrow-derived cells contribute to esophageal squamous cell ${ }^{12,113}$ and metaplasia of $\mathrm{BE},{ }^{113,114}$ which is similar to chronic inflammation induced bone marrow-derived cells involved in gastric cancer. Due to current knowledge, there is one and three possible derivation of cancer stem cells for esophageal and gastric cancer, respectively. Because of heterogeneity and different etiology of two tumors, more types of cancer stem cells will be revealed in the future. A subpopulation of esophageal basal cells has characteristics of stem cells. ${ }^{115}$ Studies of cell surface markers identifying 
esophageal cancer stem-like cell are preliminary. Lgr5 (an intestinal stem cell marker), ${ }^{116,117}$ P75 neurotrophin receptor ${ }^{118-120}$ are potential candidate biomarkers. Previously established cancer stem cell markers, CD24, CD29, CD44 and beta-catenin, were not the markers for cancer stem cells in EAC. ${ }^{121}$ Side population cells from EC9706, EC109 cells ${ }^{122}$, primary ESCC tissue, ${ }^{123}$ possessed the properties of cancer stem cell. NS398, a cyclooxygenase-2 inhibitor, enhanced the radiosensitivity of esophageal cancer stem-like cells by down regulating beta-catenin. ${ }^{124}$ However, roles of the Hh pathway in esophageal cancer stem-like cells have not been reported. We are looking forward to the progression on this subject.

\section{MPLI CATI ONS OF THE Hh PATHWAY I N GASTROESOPHAGEAL CANCER THERAPY}

Hh signaling plays crucial roles in initiation, proliferation, metastasis and survival in gastroesophageal cancer, which provide novel target for therapy. Activation of the Hh pathway after chemoradiotherapy in esophageal cancer promotes tumor reoccurrence, ${ }^{125,126}$ and associates with the resistance to chemoradiotherapy, ${ }^{127}$ indicating that combination of $\mathrm{Hh}$ pathway inhibitor and chemoradiotherapy may improve prognosis of esophageal cancer. Recent study finds that Gli1 is a novel target of ursodeoxycholic acid-aspirin combined treatment. ${ }^{128}$

Cyclopamine, a SMO antagonist, inhibits proliferation of gastric cancer cells, ${ }^{43}$ however, in acid environment reduced efficiency of cyclopamine is found. ${ }^{129}$ Therefore, design of acid-proof cyclopamine analogues, such as IPI-926, may help to improve treatment in gastric cancer. Additionally, tumorspheres from gastric cancer cell line HGC-27 has higher chemoresistance than adherent cells. Blocking Hh signaling enhances the efficacy of chemotherapeutic drugs in tumorspheres. ${ }^{95}$

GDC-0449, an Hh pathway inhibitor, had great effects in therapy of advanced BCC and medulloblastoma. ${ }^{33,34}$ A medulloblastoma patient developed a D473H resistance mutation in SMO during the treatment of GDC-0449 and ultimately relapsed. Further analysis revealed that substitution of D473 with positively charged residues showed potential oncogenic property and identified several inhibitors against these resistant mutations. However, up-regulation of Gli2 and cyclin D1 (target gene of the Hh pathway) were found in other resistant models, suggesting that components downstream of SMO may also develop the resistance. Interestingly, the GDC-0449 resistant models regained sensitivity to PI3K inhibition. ${ }^{130}$ Studies indicate that there is limitation applying Hh pathway inhibitors alone in cancer treatment. In addition, the Hh pathway is crucial in sustain cancer stem cells which are resistant to chemoradiotherapeutic drugs. Therefore, efficacy of combination of Hh pathway inhibitors with conventional therapy is evaluated in various cancer models (Table 1). Hh pathway inhibitors, mostly SMO antagonists, showed synergistic effects with chemoradiotherapeutic agents and inhibitors of pathways and molecular in cancer treatment. However, not all the combination therapy conferred more efficiency. Combination of hepatocyte growth factor neutralization antibody L2G7 with Shh neutralization antibody 5E1 or cyclopamine failed to improve survival in medulloblastoma mouse model compared with L2G7 treatment. ${ }^{131}$ This reminds us that combination therapy should depend on the context of cancers and perform preclinical test to make sure the activity of targeted pathways.

\section{SUMMARY}

In summary, increasing evidence indicate that Hh signaling is involved in gastroesophageal cancers. Understanding of the Hh pathway provides great opportunities for developing novel therapeutic strategies for human gastroesophageal cancers with activated Hh signaling.

Conflicting Interest: The authors have no conflicting interest to declare. 
Table 1 Summary of Hh pathway inhibitor combined therapy in cancer treatment.

\begin{tabular}{|c|c|c|c|c|c|}
\hline Type of cancer & Model & $\begin{array}{l}\text { Hh pathway } \\
\text { inhibitor }\end{array}$ & Combined therapy & Efficacy & Reference \\
\hline $\begin{array}{l}\text { Hepatocellular } \\
\text { carcinoma }\end{array}$ & HA22T, Sk-Hep1 cell line & $\begin{array}{l}\text { Shh antibody or } \\
\text { Gli-1 RNAi }\end{array}$ & Ionizing radiation & $\begin{array}{ll}\text { Enhance } & \text { the } \\
\text { radioresponse } & \end{array}$ & $\begin{array}{l}\text { Chen, et al } 2011 \\
103\end{array}$ \\
\hline $\begin{array}{l}\text { Pancreatic } \\
\text { adenocarcinoma }\end{array}$ & Panc-1, BxPC-3 cell line & $\begin{array}{l}\text { Smo antagonist } \\
\text { SANT-1 }\end{array}$ & $\begin{array}{l}\text { Histone deacetylases } \\
\text { inhibitor SAHA, } \\
\text { Gemcitabine }\end{array}$ & $\begin{array}{l}\text { Increase Gemcitabine } \\
\text { cytotoxicity }\end{array}$ & Chun, et al 2009 \\
\hline Glioma & cancer cell line & $\begin{array}{l}\text { Blocking } \quad \text { Hh } \\
\text { pathway }\end{array}$ & $\begin{array}{l}\text { VCR, VP16, CDDP } \\
\text { and ACNU }\end{array}$ & $\begin{array}{l}\text { Enhance cytotoxicity of } \\
\text { chemotherapertic agents }\end{array}$ & Cui, et al $2010^{132}$ \\
\hline Mantle cell lymphoma & JVM2 cell line & Cyclopamine & Doxorubicin & $\begin{array}{l}\text { Increase susceptibility to } \\
\text { doxorubicin }\end{array}$ & 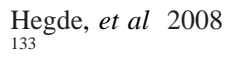 \\
\hline Pancreatic cancer & Direct xenograft model & Cyclopamine & Gemcitabine & $\begin{array}{l}\text { Induce tumor regression } \\
\text { and decrease in cancer } \\
\text { stem cell markers }\end{array}$ & 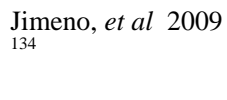 \\
\hline $\begin{array}{l}\text { Leukemia, } \\
\text { lymphoma }\end{array}$ & $\begin{array}{l}\text { Acute leukemia and B-cell } \\
\text { lymphoma cell lines }\end{array}$ & Cyclopamine & Quercertin & $\begin{array}{l}\text { Suppress the growth of } \\
\text { cancer cells }\end{array}$ & $\begin{array}{l}\text { Kawahara, et al } \\
2009^{135}\end{array}$ \\
\hline Prostate cancer & $\begin{array}{l}\text { LNCap, DU145 and PC3 } \\
\text { cell line }\end{array}$ & Cyclopamine & $\begin{array}{lr}\text { Epidermal } & \text { growth } \\
\text { factor } & \text { receptor } \\
\text { inhibitor } & \text { gefitinib, } \\
\text { docetaxel } & \end{array}$ & $\begin{array}{l}\text { Improve the cytotoxic } \\
\text { effects of docetaxel }\end{array}$ & $\begin{array}{l}\text { Mimeault, et al } \\
2007^{136}\end{array}$ \\
\hline Pancreatic cancer & in vitro and in vivo models & $\begin{array}{l}\text { Cyclopamine/ } \\
\text { CUR199691 }\end{array}$ & $\begin{array}{l}\text { Mammalian target } \\
\text { of rapamycin } \\
\text { inhibitor rapamycin, } \\
\text { chemotherapy }\end{array}$ & $\begin{array}{l}\text { Combined inhibition of } \\
\text { Hh and mTOR pathway } \\
\text { together with } \\
\text { chemotherapy reduces the } \\
\text { number of cancer stem } \\
\text { cells }\end{array}$ & $\begin{array}{l}\text { Mueller, et al } \\
2009^{137}\end{array}$ \\
\hline $\begin{array}{l}\text { Androgen-independent } \\
\text { prostate cancer }\end{array}$ & PC-3 xenograft & $\begin{array}{l}\text { Gli2 antisense } \\
\text { oligonucleotide }\end{array}$ & Paclitaxel & $\begin{array}{l}\text { Delay tumor progression } \\
\text { and enhanced paclitaxel } \\
\text { chemosensitivity }\end{array}$ & $\underset{138}{\text { Narita, et al } 2008}$ \\
\hline Leukemia & $\begin{array}{l}\text { T-cell acute lymphoblastic } \\
\text { leukemia cell lines, acute } \\
\text { myeloid leukemia cell lines }\end{array}$ & Cyclopamine & $\begin{array}{l}\text { Notch inhibitor GSI- } \\
\text { XXI, Wnt inhibitor } \\
\text { quercetin }\end{array}$ & $\begin{array}{l}\text { combination with } \\
\text { cyclopamine or quercetin } \\
\text { promotes anti-leukemic } \\
\text { effects of GSI }\end{array}$ & $\begin{array}{l}\text { Okuhashi, et al } \\
2011^{101}\end{array}$ \\
\hline $\begin{array}{l}\text { Pancreateic ductal } \\
\text { adenocarcinoma }\end{array}$ & mouse model & IPI-926 & Gemcitabine & $\begin{array}{l}\text { Enhance delivery of } \\
\text { gemcitabine }\end{array}$ & $\begin{array}{l}\text { Olive, et al } 2009 \\
139\end{array}$ \\
\hline $\begin{array}{l}\text { Medulloblastoma and } \\
\text { glioblastoma (GBM) }\end{array}$ & $\begin{array}{l}\text { GBM and medulloblastoma } \\
\text { cell lines, primary human } \\
\text { GBM cultures }\end{array}$ & Cyclopamine & $\begin{array}{l}\text { Gamma-secretase } \\
\text { inhibitor MRK-003 }\end{array}$ & $\begin{array}{l}\text { More effective at } \\
\text { eliminating GBMs cells }\end{array}$ & $\begin{array}{l}\text { Schreck, et al } \\
2010^{140}\end{array}$ \\
\hline $\begin{array}{l}\text { Androgen-independent } \\
\text { prostate cancer }\end{array}$ & LNCaP C4-2B cell line & Cyclopamine & $\begin{array}{l}\text { ErbB signaling } \\
\text { inhibitors gefitinib } \\
\text { and lapatinib }\end{array}$ & $\begin{array}{l}\text { Synergistic } \\
\text { antiproliferation effects }\end{array}$ & $\begin{array}{l}\text { Shaw and Prowse } \\
2008^{141}\end{array}$ \\
\hline Pancreatic cancer & $\begin{array}{l}\text { PANC-1, SUIT-2 and } \\
\text { ASPC-1 }\end{array}$ & Cyclopamine & $\begin{array}{l}\text { Epidermal growth } \\
\text { factor receptor } \\
\text { inhibitor Iressa }\end{array}$ & $\begin{array}{l}\text { Induce growth inhibitory } \\
\text { and apoptosis }\end{array}$ & $\mathrm{Hu}$, et al $2007^{30}$ \\
\hline Cholangiocarcinoma & $\begin{array}{l}\text { Cholangiocarcinoma cell } \\
\text { lines }\end{array}$ & Cyclopamine & $\begin{array}{l}\text { MEK inhibitor } \\
\text { U0126 }\end{array}$ & $\begin{array}{l}\text { Decease proliferation and } \\
\text { survival }\end{array}$ & $\begin{array}{l}\text { Jinawath, et al } \\
2007^{142}\end{array}$ \\
\hline Prostate cancer & $\begin{array}{l}\text { LNCaP-C33, LNCaP-LN3, } \\
\text { LNCaP-C81, DU145 and } \\
\text { PC3 cell line }\end{array}$ & Cyclopamine & $\begin{array}{l}\text { Epidermal growth } \\
\text { factor receptor } \\
\text { inhibitor gefitinib, }\end{array}$ & $\begin{array}{l}\text { Growth arrest and } \\
\text { apoptosis }\end{array}$ & $\begin{array}{l}\text { Mimeault, et al } \\
2006^{143}\end{array}$ \\
\hline Esophageal cancer & SEG-1,BE-3 cell line & Cyclopamine & Ionizing radiation & $\begin{array}{l}\text { Enhance } \\
\text { cytotoxicity }\end{array}$ & $\begin{array}{l}\text { Sims-Mourtada, et } \\
\text { al } 2006^{126}\end{array}$ \\
\hline
\end{tabular}

\section{REFERENCES}

[1] Nusslein-Volhard C, Wieschaus E. Mutations affecting segment number and polarity in Drosophila. Nature 1980;287:795-801. http://dx.doi.org/10.1038/287795a0

[2] Krauss S, Concordet JP, Ingham PW. A functionally conserved homolog of the Drosophila segment polarity gene hh is expressed in tissues with polarizing activity in zebrafish embryos. Cell 1993;75:1431-1444. http://dx.doi.org/10.1016/0092-8674(93)90628-4

[3] Echelard Y, Epstein DJ, St-Jacques B, Shen L, Mohler J, McMahon JA, et al. Sonic hedgehog, a member of a family of putative signaling molecules, is implicated in the regulation of CNS polarity. Cell 1993;75:1417-1430. http://dx.doi.org/10.1016/0092-8674(93)90627-3

[4] Riddle RD, Johnson RL, Laufer E, Tabin C. Sonic hedgehog mediates the polarizing activity of the ZPA. Cell 1993;75:1401-1416. http://dx.doi.org/10.1016/0092-8674(93)90626-2 
[5] Chang DT, Lopez A, von Kessler DP, Chiang C, Snimandl BK, Zhao R, et al. Products, genetic linkage and limb patterning activity of a murine hedgehog gene. Development 1994;120:3339-3353. PMid:7720571

[6] Roelink H, Augsburger A, Heemskerk J, Korzh V, Norlin S, Ruiz i Altava A, et al. Floor plate and motor neuron induction by vhh-1, a vertebrate homolog of hedgehog expressed by the notochord. Cell 1994;76:761-775. http://dx.doi.org/10.1016/0092-8674(94)90514-2

[7] Ingham PW, Placzek M. Orchestrating ontogenesis: variations on a theme by sonic hedgehog. Nat Rev Genet 2006;7:841-850. http://dx.doi.org/10.1038/nrg1969 PMid:17047684

[8] Sasaki H, Hui C, Nakafuku M, Kondoh H. A binding site for Gli proteins is essential for HNF-3beta floor plate enhancer activity in transgenics and can respond to Shh in vitro. Development 1997;124:1313-1322. PMid:9118802

[9] Kinzler KW, Vogelstein B. The GLI gene encodes a nuclear protein which binds specific sequences in the human genome. Mol Cell Biol 1990;10:634-642. PMid:2105456 PMCid:360861

[10] Bale AE. Hedgehog signaling and human disease. Annu Rev Genomics Hum Genet 2002;3:47-65. http://dx.doi.org/10.1146/annurev.genom.3.022502.103031 PMid:12142354

[11] Xie J. Hedgehog signaling in prostate cancer. Future Oncology 2005;1:331-338. http://dx.doi.org/10.1517/14796694.1.3.331 PMid:16556007

[12] Xie J. Hedgehog signaling pathway: development of antagonists for cancer therapy. Curr Oncol Rep 2008;10:107-113. http://dx.doi.org/10.1007/s11912-008-0018-7 PMid:18377823

[13] Xie J. Molecular biology of basal and squamous cell carcinomas. Adv Exp Med Biol 2008;624:241-251. http://dx.doi.org/10.1007/978-0-387-77574-6_19 PMid:18348461

[14] Bailey JM, Mohr AM, Hollingsworth MA. Sonic hedgehog paracrine signaling regulates metastasis and lymphangiogenesis in pancreatic cancer. Oncogene 2009;28:3513-3525. http://dx.doi.org/10.1038/onc.2009.220 PMid:19633682 PMCid:2910592

[15] Feldmann G, Dhara S, Fendrich V, Bedja D, Beaty R, Mullendore M, et al. Blockade of hedgehog signaling inhibits pancreatic cancer invasion and metastases: a new paradigm for combination therapy in solid cancers. Cancer Res 2007;67:2187-2196. http://dx.doi.org/10.1158/0008-5472.CAN-06-3281 PMid:17332349 PMCid:3073370

[16] Pasca di Magliano M, Sekine S, Ermilov A, Ferris J, Dlugosz AA, Hebrok M. Hedgehog/Ras interactions regulate early stages of pancreatic cancer. Genes Dev 2006;20:3161-3173. http://dx.doi.org/10.1101/gad.1470806

[17] Inaguma S, Kasai K, Ikeda H. GLI1 facilitates the migration and invasion of pancreatic cancer cells through MUC5AC-mediated attenuation of E-cadherin. Oncogene 2011;30:714-723. http://dx.doi.org/10.1038/onc.2010.459 PMid:20972463

[18] Dai J, Ai K, Du Y, Chen G. Sonic hedgehog expression correlates with distant metastasis in pancreatic adenocarcinoma. Pancreas 2011;40:233236. http://dx.doi.org/10.1097/MPA.0b013e3181f7e09f PMid:20938369

[19] Thayer SP, di Magliano MP, Heiser PW, Nielsen CM, Roberts DJ, Lauwers GY, et al. Hedgehog is an early and late mediator of pancreatic cancer tumorigenesis. Nature 2003;425:851-856. http://dx.doi.org/10.1038/nature02009 PMid:14520413

[20] Nolan-Stevaux O, Lau J, Truitt ML, Chu GC, Hebrok M, Fernández-Zapico ME, et al. GLI1 is regulated through Smoothened-independent mechanisms in neoplastic pancreatic ducts and mediates PDAC cell survival and transformation. Genes Dev 2009;23:24-36. http://dx.doi.org/10.1101/gad.1753809

[21] Morton JP, Mongeau ME, Klimstra DS, Morris JP, Lee YC, Kawaguchi Y, et al. Sonic hedgehog acts at multiple stages during pancreatic tumorigenesis. Proc Natl Acad Sci U S A 2007;104:5103-5108. http://dx.doi.org/10.1073/pnas.0701158104 PMid:17372229 PMCid:1828712

[22] Ji Z, Mei FC, Xie J, Cheng X. Oncogenic KRAS activates hedgehog signaling pathway in pancreatic cancer cells. J Biol Chem 2007;282:1404814055. http://dx.doi.org/10.1074/jbc.M611089200 PMid:17353198

[23] Dembinski JL, Krauss S. Characterization and functional analysis of a slow cycling stem cell-like subpopulation in pancreas adenocarcinoma. Clin Exp Metastasis 2009;26:611-623. http://dx.doi.org/10.1007/s10585-009-9260-0

[24] Gaviraghi M, Tunici P, Valensin S, Rossi M, Giordano C, Magnoni L, et al. Pancreatic cancer spheres are more than just aggregates of stem marker-positive cells. Biosci Rep 2010;31:45-55. http://dx.doi.org/10.1042/BSR20100018 PMid:20426768 PMCid:2990923

[25] Kelleher FC. Hedgehog signaling and therapeutics in pancreatic cancer. Carcinogenesis 2011;32:445-451. http://dx.doi.org/10.1093/carcin/bgq280 PMid:21186299

[26] Feldmann G, Habbe N, Dhara S, Bisht S, Alvarez H, Fendrich V, et al. Hedgehog inhibition prolongs survival in a genetically engineered mouse model of pancreatic cancer. Gut 2008;57:1420-1430. 
http://dx.doi.org/10.1136/gut.2007.148189

PMid:18515410 PMCid:2707354

[27] Feldmann G, Fendrich V, McGovern K, Bedja D, Bisht S, Alvarez H, et al. An orally bioavailable small-molecule inhibitor of Hedgehog signaling inhibits tumor initiation and metastasis in pancreatic cancer. Mol Cancer Ther 2008;7:2725-2735. http://dx.doi.org/10.1158/1535-7163.MCT-08-0573 PMid:18790753 PMCid:2605523

[28] Cheng H, Merika E, Syrigos KN, Saif MW. Novel agents for the treatment of pancreatic adenocarcinoma. Highlights from the "2011 ASCO Annual Meeting". Chicago, IL, USA; June 3-7, 2011. JOP 2011;12:334-338. PMid:21737890

[29] Chun SG, Zhou W, Yee NS. Combined targeting of histone deacetylases and hedgehog signaling enhances cytoxicity in pancreatic cancer. Cancer Biol Ther 2009;8:1328-1339. http://dx.doi.org/10.4161/cbt.8.14.8633

[30] Hu WG, Liu T, Xiong JX, Wang CY. Blockade of sonic hedgehog signal pathway enhances antiproliferative effect of EGFR inhibitor in pancreatic cancer cells. Acta Pharmacol Sin 2007;28:1224-1230. http://dx.doi.org/10.1111/j.1745-7254.2007.00620.x PMid:17640486

[31] Chen JK, Taipale J, Cooper MK, Beachy PA. Inhibition of Hedgehog signaling by direct binding of cyclopamine to Smoothened. Genes Dev 2002;16:2743-2748. http://dx.doi.org/10.1101/gad.1025302

[32] Sheridan C. Genentech obtains proof of concept for hedgehog inhibition. Nat Biotechnol 2009;27:968-969. http://dx.doi.org/10.1038/nbt1109-968 PMid:19898437

[33] Von Hoff DD, LoRusso PM, Rudin CM, Reddy JC, Yauch RL, Tibes R, et al. Inhibition of the hedgehog pathway in advanced basal-cell carcinoma. N Engl J Med 2009;361:1164-1172. http://dx.doi.org/10.1056/NEJMoa0905360 PMid:19726763

[34] Dlugosz AA, Talpaz M. Following the hedgehog to new cancer therapies. N Engl J Med 2009;361:1202-1205. http://dx.doi.org/10.1056/NEJMe0906092 PMid:19726764

[35] Jemal A, Siegel R, Ward E, Hao Y, Xu J, Murray T, et al. Cancer statistics, 2008. CA Cancer J Clin 2008;58:71-96. http://dx.doi.org/10.3322/CA.2007.0010 PMid:18287387

[36] Crane LM, Schaapveld M, Visser O, Louwman MW, Plukker JT, van Dam GM. Oesophageal cancer in The Netherlands: increasing incidence and mortality but improving survival. Eur J Cancer 2007;43:1445-1451. http://dx.doi.org/10.1016/j.ejca.2007.03.024 PMid:17512189

[37] Brown LM, Devesa SS, Chow WH. Incidence of adenocarcinoma of the esophagus among white Americans by sex, stage, and age. J Natl Cancer Inst 2008;100:1184-1187. http://dx.doi.org/10.1093/jnci/djn211 PMid:18695138 PMCid:2518165

[38] Botterweck AA, Schouten LJ, Volovics A, Dorant E, van Den Brandt PA. Trends in incidence of adenocarcinoma of the oesophagus and gastric cardia in ten European countries. Int J Epidemiol 2000;29:645-654. http://dx.doi.org/10.1093/ije/29.4.645 PMid:10922340

[39] He YT, Hou J, Chen ZF, Qiao CY, Song GH, Meng FS, et al. Decrease in the esophageal cancer incidence rate in mountainous but not level parts of Cixian County, China, over 29 years. Asian Pac J Cancer Prev 2005;6:510-514. PMid:16436002

[40] Ma X, Sheng T, Zhang Y, Zhang X, He J, Huang S, et al. Hedgehog signaling is activated in subsets of esophageal cancers. Int J Cancer 2006;118:139-148. http://dx.doi.org/10.1002/ijc.21295 PMid:16003737

[41] Xie K, Abbruzzese JL. Developmental biology informs cancer: the emerging role of the hedgehog signaling pathway in upper gastrointestinal cancers. Cancer Cell 2003;4:245-247. http://dx.doi.org/10.1016/S1535-6108(03)00246-0

[42] Yang L, Bian Y, Huang S, Ma X, Zhang C, Su X, et al. Identification of signature genes for detecting hedgehog pathway activation in esophageal cancer. Pathol Oncol Res 2011;17:387-391. http://dx.doi.org/10.1007/s12253-010-9337-8

[43] Ma X, Chen K, Huang S, Zhang X, Adegboyega PA, Evers BM, et al. Frequent activation of the hedgehog pathway in advanced gastric adenocarcinomas. Carcinogenesis 2005;26:1698-1705. http://dx.doi.org/10.1093/carcin/bgi130 PMid:15905200

[44] Mori Y, Okumura T, Tsunoda S, Sakai Y, Shimada Y. Gli-1 expression is associated with lymph node metastasis and tumor progression in esophageal squamous cell carcinoma. Oncology 2006;70:378-389. http://dx.doi.org/10.1159/000098111 PMid:17179732

[45] Berman DM, Karhadkar SS, Maitra A, Montes De Oca R, Gerstenblith MR, Briggs K, et al. Widespread requirement for Hedgehog ligand stimulation in growth of digestive tract tumours. Nature 2003;425:846-851. http://dx.doi.org/10.1038/nature01972 PMid:14520411

[46] Isohata N, Aoyagi K, Mabuchi T, Daiko H, Fukaya M, Ohta H, et al. Hedgehog and epithelial-mesenchymal transition signaling in normal and malignant epithelial cells of the esophagus. Int J Cancer 2009;125:1212-1221. http://dx.doi.org/10.1002/ijc.24400 PMid:19431210

[47] Wei L, Xu Z. Cross-signaling among phosphinositide-3 kinase, mitogen-activated protein kinase and sonic hedgehog pathways exists in esophageal cancer. Int J Cancer 2010. 
[48] Wang DH, Clemons NJ, Miyashita T, Dupuy AJ, Zhang W, Szczepny A, et al. Aberrant epithelial-mesenchymal Hedgehog signaling characterizes Barrett's metaplasia. Gastroenterology 2010;138:1810-1822. http://dx.doi.org/10.1053/j.gastro.2010.01.048 PMid:20138038

[49] Sui G, Bonde P, Dhara S, Broor A, Wang J, Marti G, et al. Epidermal growth factor receptor and hedgehog signaling pathways are active in esophageal cancer cells from rat reflux model. J Surg Res 2006;134:1-9. http://dx.doi.org/10.1016/j.jss.2005.12.029 PMid:16488438

[50] Chen W, Ren XR, Nelson CD, Barak LS, Chen JK, Beachy PA, et al. Activity-dependent internalization of smoothened mediated by beta-arrestin 2 and GRK2. Science 2004;306:2257-2260. http://dx.doi.org/10.1126/science.1104135 PMid:15618519

[51] Su Y, Chen X, Klein M, Fang M, Wang S, Yang CS, et al. Phenotype of columnar-lined esophagus in rats with esophagogastroduodenal anastomosis: similarity to human Barrett's esophagus. Lab Invest 2004;84:753-765. http://dx.doi.org/10.1038/labinvest.3700079 PMid:15094711

[52] Parkin DM, Pisani P, Ferlay J. Estimates of the worldwide incidence of eighteen major cancers in 1985. Int J Cancer 1993;54:594-606. http://dx.doi.org/10.1002/ijc.2910540413

[53] Parkin DM, Bray FI, Devesa SS. Cancer burden in the year 2000. The global picture. Eur J Cancer 2001;37 Suppl 8:S4-66. http://dx.doi.org/10.1016/S0959-8049(01)00267-2

[54] Parkin DM. International variation. Oncogene 2004;23:6329-6340. http://dx.doi.org/10.1038/sj.onc.1207726 PMid:15322508

[55] Parkin DM, Bray F, Ferlay J, Pisani P. Global cancer statistics, 2002. CA Cancer J Clin 2005;55:74-108. http://dx.doi.org/10.3322/canjclin.55.2.74

[56] Dimmler A, Brabletz T, Hlubek F, Hafner M, Rau T, Kirchner T, et al. Transcription of sonic hedgehog, a potential factor for gastric morphogenesis and gastric mucosa maintenance, is up-regulated in acidic conditions. Lab Invest 2003;83:1829-1837. http://dx.doi.org/10.1097/01.LAB.0000101729.25140.0C PMid:14691301

[57] Fukaya M, Isohata N, Ohta H, Aoyagi K, Ochiya T, Saeki N, et al. Hedgehog signal activation in gastric pit cell and in diffuse-type gastric cancer. Gastroenterology 2006;131:14-29. http://dx.doi.org/10.1053/j.gastro.2006.05.008 PMid:16831586

[58] Kang DH, Han ME, Song MH, Lee YS, Kim EH, Kim HJ, et al. The role of hedgehog signaling during gastric regeneration. J Gastroenterol 2009;44:372-379. http://dx.doi.org/10.1007/s00535-009-0006-1 PMid:19291354

[59] Kim JH, Huang Z, Mo R. Gli3 null mice display glandular overgrowth of the developing stomach. Dev Dyn 2005;234:984-991. http://dx.doi.org/10.1002/dvdy.20542 PMid:16247775

[60] van den Brink GR. Hedgehog signaling in development and homeostasis of the gastrointestinal tract. Physiol Rev 2007;87:1343-1375. http://dx.doi.org/10.1152/physrev.00054.2006 PMid:17928586

[61] Haveri H, Westerholm-Ormio M, Lindfors K, Maki M, Savilahti E, Andersson LC, et al. Transcription factors GATA-4 and GATA-6 in normal and neoplastic human gastrointestinal mucosa. BMC Gastroenterol 2008;8:9. http://dx.doi.org/10.1186/1471-230X-8-9 PMid:18405344 PMCid:2323380

[62] Madison BB, McKenna LB, Dolson D, Epstein DJ, Kaestner KH. FoxF1 and FoxL1 link hedgehog signaling and the control of epithelial proliferation in the developing stomach and intestine. J Biol Chem 2009;284:5936-44. http://dx.doi.org/10.1074/jbc.M808103200 PMid:19049965 PMCid:2645837

[63] Takamoto N, You LR, Moses K, Chiang C, Zimmer WE, Schwartz RJ, et al. COUP-TFII is essential for radial and anteroposterior patterning of the stomach. Development 2005;132:2179-2189. http://dx.doi.org/10.1242/dev.01808 PMid:15829524

[64] Xiao C, Ogle SA, Schumacher MA, Schilling N, Tokhunts RA, Orr-Asman MA, et al. Hedgehog signaling regulates E-cadherin expression for the maintenance of the actin cytoskeleton and tight junctions. Am J Physiol Gastrointest Liver Physiol 2010;299:G1252-1265. http://dx.doi.org/10.1152/ajpgi.00512.2009 PMid:20847300

[65] Osawa H, Ohnishi H, Takano K, Noguti T, Mashima H, Hoshino H, et al. Sonic hedgehog stimulates the proliferation of rat gastric mucosal cells through ERK activation by elevating intracellular calcium concentration. Biochem Biophys Res Commun 2006;344:680-687. http://dx.doi.org/10.1016/j.bbrc.2006.03.188 PMid:16630542

[66] Ohta H, Aoyagi K, Fukaya M, Danjoh I, Ohta A, Isohata N, et al. Cross talk between hedgehog and epithelial-mesenchymal transition pathways in gastric pit cells and in diffuse-type gastric cancers. Br J Cancer 2009;100:389-398. http://dx.doi.org/10.1038/sj.bjc.6604846 PMid:19107131 PMCid:2634717

[67] Kolterud A, Grosse AS, Zacharias WJ, Walton KD, Kretovich KE, Madison BB, et al. Paracrine Hedgehog signaling in stomach and intestine: new roles for hedgehog in gastrointestinal patterning. Gastroenterology 2009;137:618-628.

http://dx.doi.org/10.1053/j.gastro.2009.05.002

PMid:19445942 PMCid:2717174 
[68] El-Zaatari M, Zavros Y, Tessier A, Waghray M, Lentz S, Gumucio D, et al. Intracellular calcium release and protein kinase C activation stimulate sonic hedgehog gene expression during gastric acid secretion. Gastroenterology 2010;139:2061-71 e2.

[69] Minegishi Y, Suzuki H, Arakawa M, Fukushima Y, Masaoka T, Ishikawa T, et al. Reduced Shh expression in TFF2-overexpressing lesions of the gastric fundus under hypochlorhydric conditions. J Pathol 2007;213:161-169. http://dx.doi.org/10.1002/path.2221 PMid:17763396

[70] Faller G, Kirchner T. Immunological and morphogenic basis of gastric mucosa atrophy and metaplasia. Virchows Arch 2005;446:1-9. http://dx.doi.org/10.1007/s00428-004-1157-3 PMid:15583929

[71] Waghray M, Zavros Y, Saqui-Salces M, El-Zaatari M, Alamelumangapuram CB, Todisco A, et al. Interleukin-1beta promotes gastric atrophy through suppression of Sonic Hedgehog. Gastroenterology 2010;138:562-72, 72 e1-2.

[72] Xiao C, Ogle SA, Schumacher MA, Orr-Asman MA, Miller ML, Lertkowit N, et al. Loss of parietal cell expression of Sonic hedgehog induces hypergastrinemia and hyperproliferation of surface mucous cells. Gastroenterology 2010;138:550-61, 61 e1-8.

[73] Yamanaka Y, Shiotani A, Fujimura Y, Ishii M, Fujita M, Matsumoto H, et al. Expression of Sonic hedgehog (SHH) and CDX2 in the columnar epithelium of the lower oesophagus. Dig Liver Dis 2011;43:54-59. http://dx.doi.org/10.1016/j.dld.2010.04.014 PMid:20619754

[74] Mutoh H, Hayakawa H, Sashikawa M, Sakamoto H, Sugano K. Direct repression of Sonic Hedgehog expression in the stomach by Cdx2 leads to intestinal transformation. Biochem J 2010;427:423-434. http://dx.doi.org/10.1042/BJ20091177 PMid:20199401

[75] Lee SY, Han HS, Lee KY, Hwang TS, Kim JH, Sung IK, et al. Sonic hedgehog expression in gastric cancer and gastric adenoma. Oncol Rep 2007;17:1051-1055. PMid:17390043

[76] Wang LH, Choi YL, Hua XY, Shin YK, Song YJ, Youn SJ, et al. Increased expression of sonic hedgehog and altered methylation of its promoter region in gastric cancer and its related lesions. Mod Pathol 2006;19:675-683. http://dx.doi.org/10.1038/modpathol.3800573 PMid:16528374

[77] Yanai K, Nagai S, Wada J, Yamanaka N, Nakamura M, Torata N, et al. Hedgehog signaling pathway is a possible therapeutic target for gastric cancer. J Surg Oncol 2007;95:55-62. http://dx.doi.org/10.1002/jso.20606 PMid:17192867

[78] Ohta M, Tateishi K, Kanai F, Watabe H, Kondo S, Guleng B, et al. p53-Independent negative regulation of p21/cyclin-dependent kinaseinteracting protein 1 by the sonic hedgehog-glioma-associated oncogene 1 pathway in gastric carcinoma cells. Cancer Res 2005;65:10822-10829. http://dx.doi.org/10.1158/0008-5472.CAN-05-0777 PMid:16322228

[79] Yoo YA, Kang MH, Kim JS, Oh SC. Sonic hedgehog signaling promotes motility and invasiveness of gastric cancer cells through TGF-betamediated activation of the ALK5-Smad 3 pathway. Carcinogenesis 2008;29:480-490. http://dx.doi.org/10.1093/carcin/bgm281 PMid:18174246

[80] Han ME, Lee YS, Baek SY, Kim BS, Kim JB, Oh SO. Hedgehog signaling regulates the survival of gastric cancer cells by regulating the expression of Bcl-2. Int J Mol Sci 2009;10:3033-3043. http://dx.doi.org/10.3390/ijms10073033 PMid:19742123 PMCid:2738910

[81] Shiotani A, Iishi H, Uedo N, Ishiguro S, Tatsuta M, Nakae Y, et al. Evidence that loss of sonic hedgehog is an indicator of Helicobater pyloriinduced atrophic gastritis progressing to gastric cancer. Am J Gastroenterol 2005;100:581-587. http://dx.doi.org/10.1111/j.1572-0241.2005.41001.x PMid:15743355

[82] Nishizawa T, Suzuki H, Masaoka T, Minegishi Y, Iwasahi E, Hibi T. Helicobacter pylori eradication restored sonic hedgehog expression in the stomach. Hepatogastroenterology 2007;54:697-700. PMid:17591044

[83] Nishizawa T, Suzuki H, Nakagawa I, Ninegishi Y, Masaoka T, Iwasaki E, et al. Early Helicobacter pylori eradication restores sonic hedgehog expression in the gastric mucosa of Mongolian gerbils. Digestion 2009;79:99-108. http://dx.doi.org/10.1159/000209219 PMid:19295210

[84] Shiotani A, Uedo N, Iishi H, Tatsuta M, Ishiguro S, Nakae Y, et al. Re-expression of sonic hedgehog and reduction of CDX2 after Helicobacter pylori eradication prior to incomplete intestinal metaplasia. Int J Cancer 2007;121:1182-1189. http://dx.doi.org/10.1002/ijc.22835 PMid:17520681

[85] Kim JH, Choi YJ, Lee SH, Shin HS, Lee IO, Kim YJ, et al. Effect of Helicobacter pylori infection on the sonic hedgehog signaling pathway in gastric cancer cells. Oncol Rep 2010;23:1523-1528. PMid:20428805

[86] Lee KM, Lee JS, Jung HS, Park DK, Park HS, Hahm KB. Late reactivation of sonic hedgehog by Helicobacter pylori results in population of gastric epithelial cells that are resistant to apoptosis: implication for gastric carcinogenesis. Cancer Lett 2010;287:44-53. http://dx.doi.org/10.1016/j.canlet.2009.05.032 PMid:19540662

[87] Seto M, Ohta M, Asaoka Y, Ikenoue T, Tada M, Miyabayashi K, et al. Regulation of the hedgehog signaling by the mitogen-activated protein kinase cascade in gastric cancer. Mol Carcinog 2009;48:703-712. http://dx.doi.org/10.1002/mc.20516 PMid:19142899

[88] Yanai K, Nakamura M, Akiyoshi T, Nagai S, Wada J, Koga K, et al. Crosstalk of hedgehog and Wnt pathways in gastric cancer. Cancer Lett 2008;263:145-156. 
http://dx.doi.org/10.1016/j.canlet.2007.12.030

PMid:18243529

[89] Kim JH, Shin HS, Lee SH, Lee I, Lee YS, Park JC, et al. Contrasting activity of Hedgehog and Wnt pathways according to gastric cancer cell differentiation: relevance of crosstalk mechanisms. Cancer Sci 2010;101:328-335. http://dx.doi.org/10.1111/j.1349-7006.2009.01395.x PMid:19930158

[90] He J, Sheng T, Stelter AA, Li C, Zhang X, Sinha M, et al. Suppressing Wnt signaling by the hedgehog pathway through sFRP-1. J Biol Chem 2006;281:35598-35602. http://dx.doi.org/10.1074/jbc.C600200200 PMid:17035233

[91] Kameda C, Nakamura M, Tanaka H, Yamasaki A, Kubo M, Tanaka M, et al. Oestrogen receptor-alpha contributes to the regulation of the hedgehog signalling pathway in ERalpha-positive gastric cancer. Br J Cancer 2010;102:738-747.

http://dx.doi.org/10.1038/sj.bjc.6605517 PMid:20087349 PMCid:2837575

[92] Clarke MF, Dick JE, Dirks PB, Eaves CJ, Jamieson CH, Jones DL, et al. Cancer stem cells--perspectives on current status and future directions: AACR Workshop on cancer stem cells. Cancer Res 2006;66:9339-9344. http://dx.doi.org/10.1158/0008-5472.CAN-06-3126 PMid:16990346

[93] Bonnet D, Dick JE. Human acute myeloid leukemia is organized as a hierarchy that originates from a primitive hematopoietic cell. Nat Med 1997;3:730-737. http://dx.doi.org/10.1038/nm0797-730 PMid:9212098

[94] Takaishi S, Okumura T, Tu S, Wang SS, Shibata W, Vigneshwaran R, et al. Identification of gastric cancer stem cells using the cell surface marker CD44. Stem Cells 2009;27:1006-1020. http://dx.doi.org/10.1002/stem.30 PMid:19415765 PMCid:2746367

[95] Song Z, Yue W, Wei B, Wang N, Li T, Guan L, et al. Sonic hedgehog pathway is essential for maintenance of cancer stem-like cells in human gastric cancer. PLoS One 2011;6:e17687. http://dx.doi.org/10.1371/journal.pone.0017687 PMid:21394208 PMCid:3048871

[96] Ishigami S, Ueno S, Arigami T, Uchikado Y, Setoyama T, Arima H, et al. Prognostic impact of CD133 expression in gastric carcinoma. Anticancer Res 2010;30:2453-2457. PMid:20651407

[97] Reinisch C, Kandutsch S, Uthman A, Pammer J. BMI-1: a protein expressed in stem cells, specialized cells and tumors of the gastrointestinal tract. Histol Histopathol 2006;21:1143-1149. PMid:16874656

[98] Fukuda K, Saikawa Y, Ohashi M, Kumagai K, Kitajima M, Okano H, et al. Tumor initiating potential of side population cells in human gastric cancer. Int J Oncol 2009;34:1201-1207. PMid:19360333

[99] Nishii T, Yashiro M, Shinto O, Sawada T, Ohira M, Hirakawa K. Cancer stem cell-like SP cells have a high adhesion ability to the peritoneum in gastric carcinoma. Cancer Sci 2009;100:1397-1402. http://dx.doi.org/10.1111/j.1349-7006.2009.01211.x PMid:19493275

[100] Wang H, Ge G, Uchida Y, Luu B, Ahn S. Gli3 is required for maintenance and fate specification of cortical progenitors. J Neurosci 2011;31:6440-6448. http://dx.doi.org/10.1523/JNEUROSCI.4892-10.2011 PMid:21525285

[101] Okuhashi Y, Itoh M, Nara N, Tohda S. Effects of combination of notch inhibitor plus hedgehog inhibitor or Wnt inhibitor on growth of leukemia cells. Anticancer Res 2011;31:893-896. PMid:21498710

[102] Goldberg LH, Landau JM, Moody MN, Kazakevich N, Holzer AM, Myers A. Resolution of Odontogenic Keratocysts of the Jaw in Basal Cell Nevus Syndrome With GDC-0449. Arch Dermatol 2011.

[103] Chen YJ, Lin CP, Hsu ML, Shieh HR, Chao NK, Chao KS. Sonic hedgehog signaling protects human hepatocellular carcinoma cells against ionizing radiation in an autocrine manner. Int J Radiat Oncol Biol Phys 2011;80:851-859. http://dx.doi.org/10.1016/j.ijrobp.2011.01.003 PMid:21377281

[104] Curtin JC, Lorenzi MV. Drug discovery approaches to target Wnt signaling in cancer stem cells. Oncotarget 2010;1:563-577. PMid:21317452

[105] Clement V, Sanchez P, de Tribolet N, Radovanovic I, Ruiz i Altaba A. HEDGEHOG-GLI1 signaling regulates human glioma growth, cancer stem cell self-renewal, and tumorigenicity. Curr Biol 2007;17:165-172. http://dx.doi.org/10.1016/j.cub.2006.11.033 PMid:17196391 PMCid:1855204

[106] Takezaki T, Hide T, Takanaga H, Nakamura H, Kuratsu J, Kondo T. Essential role of the Hedgehog signaling pathway in human gliomainitiating cells. Cancer Sci 2011;102:1306-1312. http://dx.doi.org/10.1111/j.1349-7006.2011.01943.x PMid:21453386

[107] Uchida H, Arita K, Yunoue S, Yonezawa H, Shinsato Y, Kawano H, et al. Role of sonic hedgehog signaling in migration of cell lines established from CD133-positive malignant glioma cells. J Neurooncol 2011.

[108] Tanaka H, Nakamura M, Kameda C, Kubo M, Sato N, Kuroki S, et al. The Hedgehog signaling pathway plays an essential role in maintaining the CD44+CD24-/low subpopulation and the side population of breast cancer cells. Anticancer Res 2009;29:2147-2157. PMid:19528475

[109] Liu S, Dontu G, Mantle ID, Patel S, Ahn NS, Jackson KW, et al. Hedgehog signaling and Bmi-1 regulate self-renewal of normal and malignant human mammary stem cells. Cancer Res 2006;66:6063-6071. http://dx.doi.org/10.1158/0008-5472.CAN-06-0054 PMid:16778178 
[110] Zhao C, Chen A, Jamieson CH, Fereshteh M, Abrahamsson A, Blum J, et al. Hedgehog signalling is essential for maintenance of cancer stem cells in myeloid leukaemia. Nature 2009;458:776-779.

http://dx.doi.org/10.1038/nature07737

PMid:19169242 PMCid:2946231

[111] Dierks C, Beigi R, Guo GR, Zirlik K, Stegert MR, Manley P, et al. Expansion of Bcr-Abl-positive leukemic stem cells is dependent on Hedgehog pathway activation. Cancer Cell 2008;14:238-249. http://dx.doi.org/10.1016/j.ccr.2008.08.003 PMid:18772113

[112] Epperly MW, Guo H, Shen H, Niu Y, Zhang X, Jefferson M, et al. Bone marrow origin of cells with capacity for homing and differentiation to esophageal squamous epithelium. Radiat Res 2004;162:233-240. http://dx.doi.org/10.1667/RR3224 PMid:15333000

[113] Hutchinson L, Stenstrom B, Chen D, Piperdi B, Levey S, Lyle S, et al. Human Barrett's adenocarcinoma of the esophagus, associated myofibroblasts, and endothelium can arise from bone marrow-derived cells after allogeneic stem cell transplant. Stem Cells Dev 2011;20:11-17. http://dx.doi.org/10.1089/scd.2010.0139 PMid:20677919

[114] Sarosi G, Brown G, Jaiswal K, Feagins LA, Lee E, Crook TW, et al. Bone marrow progenitor cells contribute to esophageal regeneration and metaplasia in a rat model of Barrett's esophagus. Dis Esophagus 2008;21:43-50. PMid:18197938

[115] Kalabis J, Oyama K, Okawa T, Nakagawa H, Michaylira CZ, Stairs DB, et al. A subpopulation of mouse esophageal basal cells has properties of stem cells with the capacity for self-renewal and lineage specification. J Clin Invest 2008;118:3860-3869. PMid:19033657 PMCid:2579884

[116] Becker L, Huang Q, Mashimo H. Lgr5, an intestinal stem cell marker, is abnormally expressed in Barrett's esophagus and esophageal adenocarcinoma. Dis Esophagus 2010;23:168-174. http://dx.doi.org/10.1111/j.1442-2050.2009.00979.x PMid:19549212

[117] von Rahden BH, Kircher S, Lazariotou M, Reiber C, Stuermer L, Otto C, et al. LgR5 expression and cancer stem cell hypothesis: clue to define the true origin of esophageal adenocarcinomas with and without Barrett's esophagus? J Exp Clin Cancer Res 2011;30:23. http://dx.doi.org/10.1186/1756-9966-30-23

[118] Huang SD, Yuan Y, Liu XH, Gong DJ, Bai CG, Wang F, et al. Self-renewal and chemotherapy resistance of p75NTR positive cells in esophageal squamous cell carcinomas. BMC Cancer 2009;9:9.

http://dx.doi.org/10.1186/1471-2407-9-9

PMid:19134212 PMCid:2637890

[119] Sun ZG, Huang SD, Zhang BR, Xu ZY, Liu XH, Gong DJ, et al. [Isolation and identification of cancer stem cells from human esophageal carcinoma]. Zhonghua Yi Xue Za Zhi 2009;89:291-295. PMid:19563702

[120] Okumura T, Shimada Y, Imamura M, Yasumoto S. Neurotrophin receptor p75(NTR) characterizes human esophageal keratinocyte stem cells in vitro. Oncogene 2003;22:4017-4026. http://dx.doi.org/10.1038/sj.onc.1206525 PMid:12821936

[121] Grotenhuis BA, Dinjens WN, Wijnhoven BP, Sonneveld P, Sacchetti A, Franken PF, et al. Barrett's oesophageal adenocarcinoma encompasses tumour-initiating cells that do not express common cancer stem cell markers. J Pathol 2010;221:379-389. PMid:20549647

[122] Huang D, Gao Q, Guo L, Zhang C, Jiang W, Li H, et al. Isolation and identification of cancer stem-like cells in esophageal carcinoma cell lines. Stem Cells Dev 2009;18:465-473. http://dx.doi.org/10.1089/scd.2008.0033 PMid:18680391

[123] Li H, Gao Q, Guo L, Lu SH. The PTEN/PI3K/Akt pathway regulates stem-like cells in primary esophageal carcinoma cells. Cancer Biol Ther 2011;11:950-958. http://dx.doi.org/10.4161/cbt.11.11.15531

[124] Che SM, Zhang XZ, Liu XL, Chen X, Hou L. The radiosensitization effect of NS398 on esophageal cancer stem cell-like radioresistant cells. Dis Esophagus 2011;24:265-273. http://dx.doi.org/10.1111/j.1442-2050.2010.01138.x PMid:21087344

[125] Yoshikawa R, Nakano Y, Tao L, Koishi K, Matsumoto T, Sasako M, et al. Hedgehog signal activation in oesophageal cancer patients undergoing neoadjuvant chemoradiotherapy. Br J Cancer 2008;98:1670-1674. http://dx.doi.org/10.1038/sj.bjc.6604361 PMid:18475300 PMCid:2391133

[126] Sims-Mourtada J, Izzo JG, Apisarnthanarax S, Wu TT, Malhotra U, Luthra R, et al. Hedgehog: an attribute to tumor regrowth after chemoradiotherapy and a target to improve radiation response. Clin Cancer Res 2006;12:6565-6572. http://dx.doi.org/10.1158/1078-0432.CCR-06-0176 PMid:17085672

[127] Zhu W, You Z, Li T, Yu C, Tao G, Hu M, et al. Correlation of hedgehog signal activation with chemoradiotherapy sensitivity and survival in esophageal squamous cell carcinomas. Jpn J Clin Oncol 2011;41:386-393. http://dx.doi.org/10.1093/jjco/hyq217 PMid:21127038

[128] Rizvi S, Demars CJ, Comba A, Gainullin VG, Rizvi Z, Almada LL, et al. Combinatorial chemoprevention reveals a novel smoothenedindependent role of GLI1 in esophageal carcinogenesis. Cancer Res 2010;70:6787-6796. http://dx.doi.org/10.1158/0008-5472.CAN-10-0197 PMid:20647328 PMCid:2954590

[129] Wilson SR, Strand MF, Krapp A, Rise F, Petersen D, Krauss S. Hedgehog antagonist cyclopamine isomerizes to less potent forms when acidified. J Pharm Biomed Anal 2010;52:707-713. 
http://dx.doi.org/10.1016/j.jpba.2010.02.017 PMid:20236786

[130] Dijkgraaf GJ, Alicke B, Weinmann L, Januario T, West K, Modrusan Z, et al. Small molecule inhibition of GDC-0449 refractory smoothened mutants and downstream mechanisms of drug resistance. Cancer Res 2011;71:435-444. http://dx.doi.org/10.1158/0008-5472.CAN-10-2876 PMid:21123452

[131] Coon V, Laukert T, Pedone CA, Laterra J, Kim KJ, Fults DW. Molecular therapy targeting Sonic hedgehog and hepatocyte growth factor signaling in a mouse model of medulloblastoma. Mol Cancer Ther 2010;9:2627-2636. http://dx.doi.org/10.1158/1535-7163.MCT-10-0486 PMid:20807782 PMCid:2937075

[132] Cui D, Xu Q, Wang K, Che X. Gli1 is a potential target for alleviating multidrug resistance of gliomas. J Neurol Sci 2010;288:156-166. http://dx.doi.org/10.1016/j.jns.2009.09.006 PMid:19818966

[133] Hegde GV, Munger CM, Emanuel K, Joshi AD, Greiner TC, Weisenburger DD, et al. Targeting of sonic hedgehog-GLI signaling: a potential strategy to improve therapy for mantle cell lymphoma. Mol Cancer Ther 2008;7:1450-1460. http://dx.doi.org/10.1158/1535-7163.MCT-07-2118 PMid:18524848

[134] Jimeno A, Feldmann G, Suarez-Gauthier A, Rasheed Z, Solomon A, Zou GM, et al. A direct pancreatic cancer xenograft model as a platform for cancer stem cell therapeutic development. Mol Cancer Ther 2009;8:310-314. http://dx.doi.org/10.1158/1535-7163.MCT-08-0924 PMid:19174553 PMCid:3033101

[135] Kawahara T, Kawaguchi-Ihara N, Okuhashi Y, Itoh M, Nara N, Tohda S. Cyclopamine and quercetin suppress the growth of leukemia and lymphoma cells. Anticancer Res 2009;29:4629-4632. PMid:20032413

[136] Mimeault M, Johansson SL, Vankatraman G, Moore E, Henichart JP, Depreux P, et al. Combined targeting of epidermal growth factor receptor and hedgehog signaling by gefitinib and cyclopamine cooperatively improves the cytotoxic effects of docetaxel on metastatic prostate cancer cells. Mol Cancer Ther 2007;6:967-978. http://dx.doi.org/10.1158/1535-7163.MCT-06-0648 PMid:17363490

[137] Mueller MT, Hermann PC, Witthauer J, Rubio-Viqueira B, Leicht SF, Huber S, et al. Combined targeted treatment to eliminate tumorigenic cancer stem cells in human pancreatic cancer. Gastroenterology 2009;137:1102-1113. http://dx.doi.org/10.1053/j.gastro.2009.05.053 PMid:19501590

[138] Narita S, So A, Ettinger S, Hayashi N, Muramaki M, Fazli L, et al. GLI2 knockdown using an antisense oligonucleotide induces apoptosis and chemosensitizes cells to paclitaxel in androgen-independent prostate cancer. Clin Cancer Res 2008;14:5769-5777. http://dx.doi.org/10.1158/1078-0432.CCR-07-4282 PMid:18794086

[139] Olive KP, Jacobetz MA, Davidson CJ, Gopinathan A, McIntyre D, Honess D, et al. Inhibition of Hedgehog signaling enhances delivery of chemotherapy in a mouse model of pancreatic cancer. Science 2009;324:1457-1461. http://dx.doi.org/10.1126/science.1171362 PMid:19460966 PMCid:2998180

[140] Schreck KC, Taylor P, Marchionni L, Gopalakrishnan V, Bar EE, Gaiano N, et al. The Notch target Hes1 directly modulates Gli1 expression and Hedgehog signaling: a potential mechanism of therapeutic resistance. Clin Cancer Res 2010;16:6060-6070. http://dx.doi.org/10.1158/1078-0432.CCR-10-1624 PMid:21169257

[141] Shaw G, Prowse DM. Inhibition of androgen-independent prostate cancer cell growth is enhanced by combination therapy targeting Hedgehog and ErbB signalling. Cancer Cell Int 2008;8:3. http://dx.doi.org/10.1186/1475-2867-8-3

PMid:18348720 PMCid:2311276

[142] Jinawath A, Akiyama Y, Sripa B, Yuasa Y. Dual blockade of the Hedgehog and ERK1/2 pathways coordinately decreases proliferation and survival of cholangiocarcinoma cells. J Cancer Res Clin Oncol 2007;133:271-278. http://dx.doi.org/10.1007/s00432-006-0166-9 PMid:17294242

[143] Mimeault M, Moore E, Moniaux N, Henichart JP, Depreux P, Lin MF, et al. Cytotoxic effects induced by a combination of cyclopamine and gefitinib, the selective hedgehog and epidermal growth factor receptor signaling inhibitors, in prostate cancer cells. Int J Cancer 2006;118:10221031.

http://dx.doi.org/10.1002/ijc.21440

PMid:16108016 